\title{
ANALISIS ELEMEN-ELEMEN BRAND EQUITY PADA PRODUK KARTU SELULER PRABAYAR SIMPATI, IM3, DAN XL DI KALANGAN MAHASISWA S1 UNIVERSITAS DIPONEGORO
}

\author{
Arfan Bakhtiar*), Dwi Jayanto \\ Jurusan Teknik Industri, Fakultas Teknik, Universitas Diponegoro, \\ Jl. Prof. Soedarto, SH, Kampus Undip Tembalang, Semarang, Indonesia 50275
}

\begin{abstract}
Abstrak
Era globalisasi menjanjikan suatu peluang dan tantangan bisnis baru bagi perusahaan yang beroperasi di Indonesia. Salah satu industri yang sangat ketat persaingannya adalah industri telekomunikasi. Di Indonesia saat ini terdapat tiga perusahaan GSM yang menguasai pasar yang bergerak dalam industri ini, perusahaan itu adalah IM3 yang dikeluarkan oleh PT. Indosat TBK, XL yang dikeluarkan PT. Excelcomindo Pratama dan Simpati yang dikeluarkan oleh PT. Telekomunikasi Seluler. Penelitian ini bertujuan untuk meneliti elemen-elemen ekuitas merek dari ketiga merek kartu telepon tersebut. Manfaat yang diperoleh dari penelitian ini adalah memberikan informasi kepada para pembaca mengenai produk kartu telepon apa yang paling diingat konsumen asosiasi-asosiasi apa saja yang melekat pada kartu-kartu telepon tersebut, produk kartu telepon apa yang memiliki tingkat loyalitas paling tinggi, serta bagaimana persepsi kualitas konsumen terhadap kartu-kartu tersebut. Pengujian hipotesis dalam penelitian ini akan menggunakan Uji Cohran. Dari hasil penelitian yang dilakukan pada tiap elemen-elemennya, didapat bahwa produk kartu Simpati adalah produk yang memiliki tingkat brand awareness paling tinggi, asosiasi produk yang paling banyak adalah Simpati dengan 7 asosiasi, tingkat loyalitas konsumen pengguna kartu telepon yang paling tinggi adalah kartu Simpati, serta kartu telepon yang memiliki brand perceived quality yang diukur berdasarkan performance dan importancenya adalah kartu Simpati.
\end{abstract}

Kata kunci: brand association; brand awareness; brand equity;brand loyalty; perceived quality

\begin{abstract}
The globalization era provides new business opportunities and challenges for industries operating in Indonesia. One of the industries that has tight competition is telecommunications industry. In Indonesia, there are currently three GSM industries that dominate the market that engaged in the industry. They are IM3, owned by Indosat TBK Ltd., XL, owned by Excelcomindo Pratama Ltd. and Simpati Ltd., owned by Telekomunikasi Seluler. This paper aims to examine the elements of brand equity of the three brands of the cards. This paper provides information to the readers about what phone card products most remembered for the consumer, what the associations are attached to the phone cards, what phone card products that have the highest levels of loyalty, and how the consumers perceived quality of the cards. Hypothesis testing in this study uses Cochran test. From the results of the research that is conducted on each of its elements, it results that: Simpati card is a product that has the highest level of brand awareness; the most product associations is Simpati product with 7 associations; the highest phone card consumer loyalty level is the Simpati card; and a phone card that has a brand perceived quality is measured based on its performance and importance is Simpati card.
\end{abstract}

Keywords: brand association; brand awareness; brand equity; brand loyalty; perceived quality

\footnotetext{
${ }^{*}$ Penulis Korespondensi. email: arfbakh@yahoo.com
} 


\section{Pendahuluan}

Pada bagian pertama pada paper ini akan menjelaskan tentang latar belakang penelitian, perumusan masalah dan bahan acuan yang digunakan. Latar belakang menjelaskan tentang alasan mengapa penelitian ini dibuat, yaitu tentang peran merek di pasaran. Merek bukan sekedar membedakan satu produk dengan yang lainnya, merek memberikan kontribusi menciptakan citra khusus bagi konsumen. Sehingga merek merupakan aset yang paling bernilai untuk perusahaan, maka dari itu peranan ekuitas merek ini diteliti. Pada bagian perumusan masalah menjelaskan permasalahan yang diteliti yang berhubungan dengan elemen-elemen ekuitas merek, yaitu tentang kartu seluler apa yang memiliki tingkat awareness paling tinggi, atribut apa yang berasosiasi, apakah ada kesenjangan antara kinerja dan harapan serta tingkat loyalitas dari masing-masing provider. Pada bagian acuan yang digunakan menjelaskan tentang teori-teori ekuitas merek yang dikemukakan dari beberapa sumber yang menjelaskan peranan ekuitas untuk meningkatnya kekuatan dari sebuah merek.Beberapa produk kartu prabayar dengan kualitas yang relatif hampir sama dapat memiliki kinerja yang berbeda di pasar karena perbedaan persepsi dalam benak pelanggan.

Saat ini persaingan perusahaan untuk memperebutkan konsumen tidak lagi terbatas pada atribut fungsional produk seperti kegunaan produk, melainkan sudah dikaitkan dengan merek yang mampu memberikan citra khusus bagi pemakainya, dengan kata lain peranan merek mengalami pergeseran. Pada tingkat persaingan yang rendah, merek hanya sekedar membedakan antar satu produk dengan produk lainnya atau merek sekedar nama (just a name). Sedangkan pada tingkat persaingan yang tinggi, merek memberikan kontribusi dalam menciptakan dan menjaga daya saing sebuah produk. Merek akan dihubungkan dengan citra khusus yang mampu memberikan asosiasi tertentu dalam benak konsumen. Di dalam perkembangannya, perusahaan semakin menyadari merek sebagai aset perusahaan yang paling bernilai (Roy Goni, 2007).

Dibandingkan dengan industri-industri lain, telekomunikasi merupakan industri yang tingkat pertumbuhannya paling tinggi. Tidaklah berlebihan bila industri telekomunikasi dianggap sebagai golden industry, karena tidak ada yang mampu menyamai tingkat pertumbuhannya. Data dari Asosiasi Telepon Seluler Indonesia (ATSI) menyebutkan, hingga akhir 2014 jumlah pelanggan seluler di Indonesia mencapai lebih dari 250 juta.

Dengan semakin banyaknya jumlah pesaing di pasar, meningkat pula ketajaman persaingan di antara merek-merek yang beroperasi di pasar dan hanya merek yang memiliki ekuitas merek yang kuat yang akan tetap mampu bersaing, merebut, dan menguasai pasar. Semakin kuatnya ekuitas merek suatu produk, semakin kuat pula daya tariknya di mata konsumen untuk mengkonsumsi produk tersebut yang selanjutnya dapat menggiring konsumen untuk melakukan pembelian serta mengantarkan perusahaan untuk meraup keuntungan dari waktu ke waktu (Durianto dkk, 2001). Karena itu, pengetahuan tentang elemen-elemen ekuitas merek dan pengukurannya sangat diperlukan untuk menyusun langkah strategis dalam meningkatkan eksistensi merek yang akhirnya dapat meningkatkan profitabilitas perusahaan.

Tantangan terbesar yang dihadapi oleh para operator seluler saat ini adalah loyalitas para pelanggan. Pasalnya, sekitar $97 \%$ struktur pelanggan seluler didominasi oleh pelanggan kartu prabayar. Pelanggan kartu prabayar ini sewaktu-waktu bisa berpindah ke operator lain. Apalagi kartu perdana prabayar sekarang bisa diperoleh di mana-mana dan dengan harga yang sangat terjangkau dengan berbagai penawaran-penawaran yang diberikan oleh operator seluler. Pada dasarnya penawaranpenawaran yang diberikan oleh operator seluler relatif sama, apakah itu dalam hal kualitas, harga, atau layanan. Beberapa produk kartu prabayar dengan kualitas yang relatif hampir sama dapat memiliki kinerja yang berbeda di pasar karena perbedaan persepsi dalam benak pelanggan.

Makalah ini membahas tentang ekuitas merek dari ketiga provider telepon seluler GSM yang konsumennya terbesar di Indonesia, dimana penelitiannya difokuskan pada mahasiswa S1 Universitas Diponegoro. Struktur pembahasan makalah ini adalalah sebagai berikut.Pada bagian 1 dijelaskan tentang latar belakang, rumusan masalah dari penelitian ini dan teori-teori yang mendasarinya. Pada bagian 2 dijelaskan tentang proses mendisain kuisioner, pengumpulan data, reponden yang terlibat model yang digunakan dan alat untuk mengolah data. Pada bagian 3 menjelaskan tentang hasil pengolahan data dan pembahasan. Pada bagian terakhir akan membahas tentang kesimpulan dan saran yang dihasilkan dalam penelitian ini.

Adapun permasalahan yang akan diteliti dalam penelitian ini hal-hal yang berhubungan dengan elemen-elemen brand equity (ekuitas merek) dari ketiga merek provider telepon seluler tersebut, yaitu:

1. Merek provider telepon seluler apakah yang memiliki tingkat brand awareness paling tinggi?

2. Atribut apa saja yang berasosisasi dengan konsumen provider telepon seluler prabayar Simpati, IM3 dan XL? 
3. Apakah terdapat kesenjangan antara kinerja persepsi kualitas (perfomance) dan harapan persepsi kualitas (importance) dari masingmasing merek provider telepon seluler yang diukur?

4. Bagaimanakah tingkatan loyalitas dari masingmasing merek provider telepon seluler yang diteliti?

Untuk memperkuat pemahaman masalah dan bagaimana menjawab permasalahan yang ada, selanjutnya akan diuraikan teori-teori yang mendasari penelitian ini.

Ekuitas merek adalah nilai tambah yang diberikan pada produk dan jasa (Rangkuti, F. 2001). Definisi lain mengenai ekuitas merek adalah seperangkat aktiva (assets) dan kewajiban (liabilities) merek yang terkait dengan sebuah merek, nama, dan simbol, yang dapat menambah atau mengurangi nilai yang diberikan oleh sebuah produk atau jasa kepada sebuah perusahaan atau pelanggan perusahaan. Aktiva dan kewajiban yang mempengaruhi ekuitas merek meliputi loyalitas merek, kesadaran merek, persepsi mutu, dan berbagai asosiasi merek lainnya, dan aset merek swamilik (misalnya, hak paten) (Bilson S., 2001). Ekuitas merek dapat tercermin dalam cara konsumen berpikir, merasa, dan bertindak dalam hubungannya dengan merek, harga, pangsa pasar, dan profitabilitas yang diberikan merek bagi perusahaan. Pendekatan berbasis pelanggan memandang ekuitas merek dari perspektif konsumen (baik perorangan maupun organisasi) (Kotler, 2000). Prinsip dari ekuitas merek berbasis pelanggan adalah bahwa kekuatan merek terletak pada apa yang dilihat, dibaca, didengar, dipelajari, dipikirkan, dirasakan pelanggan tentang merek sepanjang waktu.

Ekuitas merek berbasis pelanggan (customer based brand equity) adalah pengaruh diferensial yang dimiliki konsumen ataspengetahuan merek terhadap pemasaran merek tersebut. Sebuah merekmempunyai ekuitas merek berbasis pelanggan yang positif ketikakonsumen bereaksi lebih positif terhadap produk dan cara produk itudipasarkan ketika merek itu teridentifikasi, dibandingkan ketika merekitu tidak teridentifikasi. Sebaliknya, merek mempunyai ekuitas merekberbasis pelanggan yang negatif jika konsumen tidak terlalu menyukaiaktifitas pemasaran untuk merek itu dalam keadaan yang sama. Ada tigabahan kunci ekuitas merek berbasis pelanggan:

Pertama, ekuitas merek timbul akibat perbedaan respons konsumen. Jika tidak ada perbedaan, maka pada intinya produk nama merek merupakan suatu komoditas atau versi generik dari produk. Persaingan kemungkinan timbul dari harga.

Kedua, perbedaan respons adalah akibat pengetahuan konsumen tentang merek.Pengetahuan merek (brand knowladge) terdiri atas semua pikiran, perasaan, citra, pengalaman, keyakinan, dan lain-lain yang berhubungan dengan merek.Secara khusus, merek harus menciptakan asosiasi merek yang kuat, menyenangkan, dan unik dengan pelanggan.

Ketiga, diferensial dari konsumen yang membentuk ekuitas merek tercermin dalam persepsi, preferensiasi, dan perilaku yang berhubungan dengan semua aspek pemasaran merek.Merek yang lebih kuat menghasilkan pendapatan yang lebih besar.Tantangan bagi pemasar dalam membangun merek yang kuat adalah memastikan bahwa pelanggan memiliki jenis pengalaman yang tepat dengan produk, jasa, dan program pemasaran untuk menciptakan pengetahuan merek yang diinginkan.Pengetahuan konsumenlah yang menimbulkan perbedaan-perbedaan yang kemudian memanifestasikan diri dalam ekuitas merek (Hasan, A. 2009).

Pengakuan nilai (ekuitas) sebuah nama merek dan pengelolaan nama penting guna memperoleh keunggulan kompetitif maksimal bagi pemilik nama. Ekuitas merek yang tinggi memberikan sejumlah keunggulan kompetitif seperti perusahaan dapat mematok harga yang lebih tinggi dibandingkan para pesaing karena merek itu mempunyai mutu yang tinggi (menurut anggapan para konsumen) (Simamora, 2001).

Ditinjau dari perspektif pemasaran, Aaker (1991), mendefinisikan ekuitas merek sebagai sejumlah aset dan kewajiban yang berhubungan dengan merek, namanya dan simbol, yang menambah atau mengurangi nilai produk atau jasa bagi perusahaan atau bagi pelanggan perusahaan tersebut.Definisi Aaker menyiratkan bahwa ekuitas merek bisa bernilai bagi perusahaan (company based brand equity) dan bagi konsumen (customer based brand equity).Bagi konsumen, ekuitas merek merupakan aset yang dapat memberikan nilai tersendiri dimata pelanggannya.Aset yang dikandungnya dapat membantu pelanggan dalam menafsirkan, memproses dan menyimpan informasi yang terkait dengan produk dan merek tersebut.Ekuitas merek dapat mempengaruhi rasa percaya diri konsumen dalam pengambilan keputusan pembelian atas dasar pengalaman masa lalu dalam penggunaan atau kedekatan, asosiasi dengan berbagai karakteristik merek (Ferrinadewi, E. 2008).

Asosiasi merek menurut Aaker (1996) adalah segala hal yang berkaitan dengan ingatan mengenai merek (Durianto dkk, 2001).

Nilai dan profitabilitas dari suatu merek bukanlah terletak pada produk yang kasat mata, tetapi pada a good service. Keluhan yang muncul dari pihak konsumen bukanlah sehubungan dengan defect product, tetapi dengan sejauh mana produk dinilai mampu memenuhi harapan konsumen.Pada umumnya, sebagian besar keluhan konsumen adalah masalah bad service. Harapan service yang tinggi di pihak konsumen memang semakin meningkat akhirakhir ini. Bahkan tidak jarang kualitas permintaan 
yang tinggi berkaitan dengan upaya untuk memuaskan kebutuhan pada tingkatan yang lebih tinggi, katakanlah kebutuhan akan status, estetika, dan aktualisasi diri. Dengan sendirinya, apabila perusahaan tidak memperhitungkan value migration yang terjadi dalamthe mind of the market, daya saing perusahaan tersebut bisa memudar (Roy Goni, 2007).

Menurut Aaker dalam buku Managing Brand Equity(1991),brand equity dapat dikelompokkan ke dalam lima kategori:

a. Brand awareness (kesadaran merek)

Menunjukkan kesanggupan seorang calon pembeli untuk mengenali atau mengingat kembali bahwa suatu merek merupakan bagian dari kategori produk tersebut. Terdapat empat tingkat kesadaran merek yaitu: top of mind, brand recall, brand recognition, dan brand unaware.

b. Brand association (asosiasi merek)

Mencerminkan pencitraan suatu merek terhadap kesan tertentu dalam kaitannya dengan kebiasaan, gaya hidup, manfaat, atribut produk, geografis, harga, pesaing, selebritis, dan lain-lain.

c. Perceived Quality (persepsi kualitas)

Mencerminkan persepsi pelanggan terhadap keseluruhan kualitas/keunggulan suatu produk atau jasa layanan berkenaan dengan maksud yang diharapkan.

d. Brand loyalty (loyalitas merek)

Mencerminkan tingkat keterikatan konsumen dengan suatu merek produk. Terdapat lima tingkatan brand loyalty yaitu: switcher, habitual buyer, satisfied buyer, liking thebrand, dan committed buyer.

e. Other proprietary brand assets (aset-aset merek lainnya)

Empat elemen brand equity diluar aset-aset merek lainnya dikenal dengan elemen-elemen utama dari brand equity. Elemen brand equity yang kelima secara langsung akan dipengaruhi oleh kualitas dari empat elemen utama tersebut (Tjiptono, 2005).

\section{Bahan Dan Metode}

Dalam penelitian ini, sampel yang diambil adalah mahasiswa SI Universitas Diponegoro.Ada berbagai referensi yang dapat dipakai untuk menghitung ukuran sampel yang dipakai dalam penelitian, seperti Cohen, Slovin, dan lain-lain (Durianto dkk, 2004).Rumus yang satu dengan yang lainnya hanya terdapat sedikit ukuran sampel. Penelitian ini akan menggunakan rumus yang dikemukakan oleh Slovin.

Untuk menentukan berapa minimal sampel yang dibutuhkan maka dapat digunakan rumus Slovin dan didapatkan sampel minimal yang harus digunakan dalam penelitian ini adalah sebanyak 396 responden.Populasi yang diambil dalam penelitian ini adalah jumlah mahasiswa SI Universitas Diponegoro yang berjumlah 39134, data ini bersumber dari situs Universitas Diponegoro.

Penelitian dilakukan dengan membagikan kuesioner online melalui media google docs, adapun responden yang ditargetkan dalam penelitian in adalah sebanyak 396 orang.Dari hasil kuesioner yang disebar, terdapat 404 responden yang berpartisipasi.Data-data yang telah dikumpulkan dari hasil penelitian selanjutnya diolah dan direpresentasikan dalam bentuk tabel untuk selanjutnya dianalisis.Untuk pengukuran brand asossiciationmenggunakan software SPSS dengan Uji Cochran.

Metode yang digunakan untuk menganalisis data yang telah dikumpulkan dari para responden adalah metode perhitungan statistik. Metode statistik yang akan digunakan pada masing-masing elemen dari brand equity berbeda-beda. Model analisis yang digunakan untuk pengujian hipotesis dalam penelitian ini adalah sebagai berikut:

a. Model 1: Pengukuran Brand Awareness

Merek yang disebut pertama kali oleh responden termasuk dalam variabel top of mind. Kemudian untuk variabel brand recall, responden akan menyebutkan merek yang mereka ingat. Untuk variabel brand recognition dan brand unaware, responden akan diberikan bantuan pertanyaan mengenai beberapa merek yang diteliti, jika responden mengenal merek yang ditanyakan maka merek tersebut termasuk ke dalam variabel brand recognition. Sedangkan yang menjawab tidak mengenal merek yang ditanyakan maka itu termasuk ke dalam variabel brand unaware.

b. Model 2: Pengukuranbrand association

Untuk mengukur brand association digunakan Uji Cohran dengan melihat hasil dari uji SPSS. Jika P value kurang dari 0,05 maka H0 akan ditolak (tidak semua asosiasi benar). Lalu langkah berikutnya adalahmenguji ulang dengan cara yang sama namun asosiasi yang memiliki jawaban yaterendah tidak diikut sertakan. Jika $\mathrm{P}$ value masih kurang dari 0,05 maka H0 akan ditolak.Demikian seterusnya hingga didapat hasil dimana $\mathrm{P}$ value lebih dari 0,05. Setelah itu barulahdidapat asosiasi-asosiasi mana saja yang benar mengenai merek kartu telepon tersebut.

c. Model 3: pengukuran perceived quality Untuk menganalisis brand perceived quality ini kita menggunakan pembandingan performance dan importance dari setiap merek kartu telepon. Setiap atribut dari merek kartu telepon tersebut dicari nilai rata-ratanya. Setelah itu perbandingan rata-rata performance dan importance dirangkum dalam diagram cartesius yang terbagi atas 4 kuadran. Sumbu mendatar adalah tingkat performance, sedangkan sumbu vertikal adalah tingkat importance. Kuadran pertama bercirikan, 
performance rendah tetapi importance tinggi maka disebut juga underact. Dalam kuadran kedua, performance tinggi diikuti oleh importance yang tinggi pula sehingga keadaan ini harus terus dipelihara/maintain. Dalam kuadran ketiga tingkat performance rendah dan tingkat importance juga rendah sehingga disebut daerah lowpriority. Dalam kuadran keempat, tingkat performance tinggi tetapi tingkat importance rendah.

d. Model 4: Pengukuran brand loyalty

Penggolongan kategori berdasarkan nilai (score) yang diperoleh dilakukan dengan cara mengalikan besarnya bobot pada kategori tertentu yang telah ditetapkan dengan jumlah responden yang masuk dalam kategori yang sama. Selanjutnya, dari data yang diperoleh, dicari nilai rata-ratanya untuk mengetahui ukuran pemusatan responden. Bagian selanjutnya akan menjelaskan hasil pengolahan data dan bagaimana pembahasannya.

\section{Hasil Dan Pembahasan}

Bagian berikut ini menampilkan hasil dan pembahasan elemenbrand awareness, brand association, perceived quality dan brand loyalty yang telah dijelaskan dalam bagian pertama dan kedua.

Untuk keterangan tabel kartu Simpati $=S$, kartu IM3 = I dan kartu XL = X.Berikut ini (Tabel 1) adalah rangkuman dari hasil elemen brand awareness:

Tabel 1. Peringkat Provider Telepon Seluler Berdasarkan Variabel-Variabel Brand Awareness

\begin{tabular}{cccc}
\hline $\begin{array}{c}\text { Variabel Brand } \\
\text { Awareness }\end{array}$ & \multicolumn{3}{c}{$\begin{array}{c}\text { Peringkat Provider Telp. } \\
\text { Seluler }\end{array}$} \\
\cline { 2 - 4 } & $\mathbf{1}$ & $\mathbf{2}$ & $\mathbf{3}$ \\
\hline Top of Mind & $\mathrm{S}$ & $\mathrm{I}$ & $\mathrm{X}$ \\
Brand Recall & $\mathrm{X}$ & $\mathrm{I}$ & $\mathrm{S}$ \\
Brand & $\mathrm{X}$ & $\mathrm{I}$ & $\mathrm{S}$ \\
Recognition & & & \\
Brand Unaware & $\mathrm{X}$ & $\mathrm{I}$ & $\mathrm{S}$ \\
\hline
\end{tabular}

Ada pun kartu provider telepon yang memiliki tingkat awareness yang paling tinggi adalah kartu Simpati karena kartu Simpati merupakan kartu yang paling banyak dipilih pada variabel top of mind, di tempat kedua ditempati oleh merek IM3dan yang terakhir XL. Hal ini memang mungkin karena kedua merek ini memegang pangsa pasar provider kartu seluler terbesar di Indonesia. Sedangkan untuk kartu yang paling diingat setelah mereka menyebutkan topof mind adalah kartu XL, karena kartu XL merupakan kartu yang paling banyak dipilih pada variabel brand recall. Peringkat yang ideal disini adalah peringkat yang rendah, karena peringkat yang rendah berarti merek itu telah disebut pertama kali oleh responden. Maksud dari brand recall adalah merek yang disebut setelah merek yang disebut pertama kali, artinya merek Simpati kebanyakan disebut sebagai top of mind, disusul oleh IM3 dam XL. Kartu yang paling banyak dipilih oleh responden tetapi dengan diberikan sedikit bantuan untuk mengingatnya adalah kartu XL, karena kartu XL merupakan kartu yang paling banyak dipilih pada variabel Brand Recognition. Hal ini juga membuktikan bahwa ingatan responden akan keberadaan merek Simpati tetap lebih baik daripada IM3 dan XL, karena lebih sedikit yang harus diingatkan. Terakhir, kartu yang paling banyak tidak diketahui keberadaannya oleh responden (memiliki tingkat awareness paling rendah) adalah kartu XL, karena kartu XL merupakan kartu yang paling banyak dipilih pada variabel brand unaware.Hal ini tentu saja kurang menguntungkan bagi penjualan merek ini, karena bila responden mengenal saja tidak, bagaimana timbul keinginan untuk membeli.Pembahasan selanjutnya adalah mengenai asosiasi dari masing-masing merek, hasilnya dapat dilihat di tabel 2:

Tabel 2. AtributAsosiasi Masing-Masing Merek

\begin{tabular}{|c|c|c|c|c|}
\hline \multirow[b]{2}{*}{ No } & \multirow[b]{2}{*}{ Asosiasi/Kesan } & \multicolumn{3}{|c|}{ Merek } \\
\hline & & $\mathbf{S}$ & $\mathbf{I}$ & $\mathbf{X}$ \\
\hline 1 & $\begin{array}{l}\text { Menyediakan berbagai kuota paket } \\
\text { SMS, internet dan telepon }\end{array}$ & & $\mathbf{X}$ & $\bar{X}$ \\
\hline 2 & $\begin{array}{l}\text { Memiliki sistem masa aktif yang } \\
\text { berbeda }\end{array}$ & & $\mathbf{X}$ & \\
\hline 3 & $\begin{array}{l}\text { Menyediakan paket internet untuk } \\
\text { pengguna smartphone }\end{array}$ & $\mathbf{X}$ & $\mathbf{X}$ & $\mathbf{X}$ \\
\hline 4 & Jaringannya kuat & $\mathbf{X}$ & & \\
\hline 5 & $\begin{array}{l}\text { Kemudahan berhubungan dengan } \\
\text { pengguna kartu pra bayar lain }\end{array}$ & $\mathbf{X}$ & & $\mathbf{X}$ \\
\hline 6 & $\begin{array}{l}\text { Layanan call center mudah } \\
\text { dihubungi }\end{array}$ & $\mathbf{X}$ & & $\mathbf{X}$ \\
\hline 7 & $\begin{array}{l}\text { Tarif paket pengguna smartphone } \\
\text { terjangkau dibandingkan tarif kartu } \\
\text { pra bayar lain }\end{array}$ & & & \\
\hline 8 & $\begin{array}{l}\text { Tarif SMS dan telepon terjangkau } \\
\text { dibandingkan tarif kartu pra bayar } \\
\text { lain }\end{array}$ & & & \\
\hline 9 & $\begin{array}{l}\text { Kemudahan dalam aplikasi tranfer } \\
\text { pulsa, penggunaan nada sambung } \\
\text { pribadi }\end{array}$ & $\mathbf{X}$ & $\mathbf{X}$ & $\mathbf{X}$ \\
\hline 10 & $\begin{array}{l}\text { Bintang iklan meyakinkan konsumen } \\
\text { tentang kualitas provider }\end{array}$ & $\mathbf{X}$ & & \\
\hline 11 & $\begin{array}{l}\text { Bintang iklan berhasil } \\
\text { menyampaikan pesan iklan provider } \\
\text { dengan baik }\end{array}$ & $\mathbf{X}$ & & \\
\hline 12 & $\begin{array}{l}\text { Produk provider lebih unggul } \\
\text { dibandingkan produk sejenis yang } \\
\text { diproduksi oleh pesaing }\end{array}$ & & & \\
\hline 13 & $\begin{array}{l}\text { Provider menawarkan layanan } \\
\text { (internet, SMS, telepon) yang lebih } \\
\text { beragam }\end{array}$ & & $\mathbf{X}$ & \\
\hline
\end{tabular}


Atribut asosiasi masing-masing merek dapat dilihat dalam Tabel 2.Secara keseluruhan atribut asosiasi yang mewakili semua merek adalah menyediakan paket internet untuk pengguna smartphone dan kemudahan dalam aplikasi tranfer pulsa, penggunaan nada sambung pribadi (NSP). Sedangkan atribut yang tidak mewakili semua merek adalah tarif paket pengguna smartphone terjangkau dibandingkan tarif kartu pra bayar lain, tarif SMS dan telepon terjangkau dibandingkan tarif kartu pra bayar lain dan produk provider lebih unggul dibandingkan produk sejenis yang diproduksi oleh pesaing. Hal ini memang sesuai dengan keadaan dilapangan bahwa mahasiswa dalam memilih providerkartu telepon mencari yang tarifnya paling murah.Dari tabel 2 tersebut dapat dilihat bahwa pada atribut menyediakan berbagai kuota paket SMS, internet dan telepon hanya mewakili merek IM3 dan XL. Selanjutnya untuk atribut memiliki sistem masa katif yang berbeda hanya mewakili merek IM3. Untuk atribut menyediakan paket internet untuk pengguna smartphone mewakili semua merek. Atribut jaringannya kuat hanya mewakili merek simpati. Untuk atribut kemudahan berhubungan dengan pengguna kartu pra bayar lain hanya mewakili merek Simpati dan XL. Sementara untuk atribut layanan call center mudah dihubungi hanya mewakili merek Simpati dan XL. Untuk atribut tarif paket pengguna smartphone terjangkau dibandingkan tarif kartu pra bayar lain dan tarif SMS, telepon terjangkau dibandingkan tarif kartu pra bayar lain dan produk provider lebih unggul dibandingkan produk sejenis yang diproduksi oleh pesaingtidak ada yang mewakili ketiga merek tersebut. Untuk Atribut kemudahan dalam aplikasi transfer pulsa, penggunaan nada sambung pribadi mewakili semua merek. Sementara untuk atribut bintang iklan meyakinkan konsumen tentang kualitas provider dengan baik hanya mewakili merek Simpati. Untuk atribut bintang iklan berhasil menyampaikan pesan iklan provider dengan baik juga hanya mewakili merek Simpati. Dan yang terakhir atribut provider menawarkan layanan (internet, SMS, telepon yang lebih beragam hanya mewakili merek IM3. Pembahasan selanjutnya adalah mengenai perceived quality, dimana dalam penelitian ini menggunakan diagram cartesius sebagai alat analisisnya. Berikut pembahasan perceived quality merek Simpati:

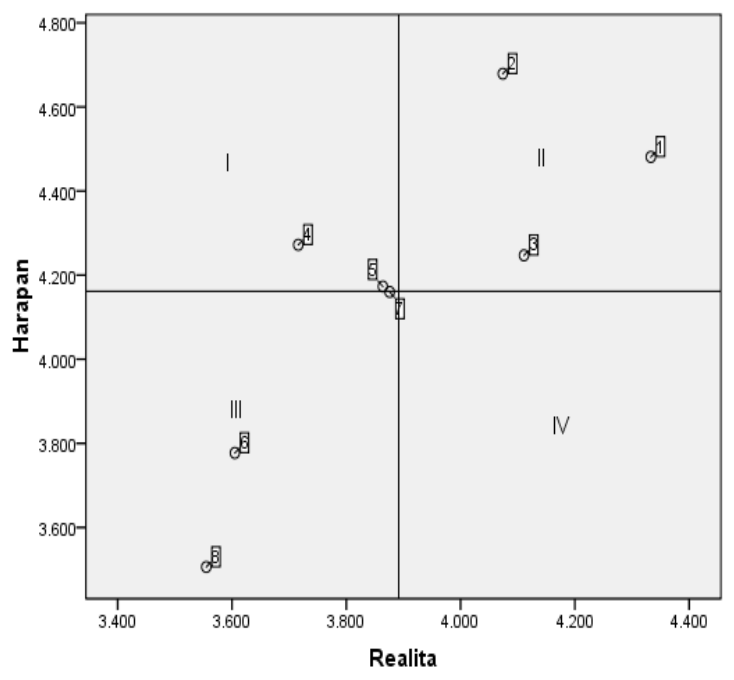

Gambar 1. Diagram Cartesius PerformanceImportance Merek Simpati

Berdasarkan Gambar 1 mengenai diagram performance dan importance dari merek kartu Simpati, dapat kita analisa bahwa atribut kecepatan layanan call center (4), atribut cepat tanggap menanggapi keluhan konsumen (5) dan atribut provider mempunyai jaminan SMS akan cepat sampai (7) adalah atribut yang menurut pengguna sangat penting, namun pada kenyataannya kinerja yang mereka terima masih buruk. Mengenai atribut kecepatan pengiriman SMS (1), jangkauan sinyal luas (2) dan keamanan data pelanggan terjaga (3) harus tetap dipertahankan dan dipelihara karena semua variabel ini menjadikan produk tersebut unggul dimata pelanggan. Atribut-atribut yang menurut pengguna tidak penting dan pada kenyataannya kinerja yang diterima juga tidak memuaskan, atributatribut ini harus ditingkatkan yaitu atribut provider mempunyai jaminan pulsa yang hilang akan dikembalikan lagi (6), dan tersedianya call center 24 jam (8).Paragraf berikutnya menjelaskan tentang perceived quality merek IM3, berikut pembahasannya:

Berdasarkan Gambar 2 mengenai diagram performance dan importance dari merek kartu IM3, dapat kita analisa bahwa atribut jangkauan sinyal luas (2), kecepatan layanan call center (4), atribut cepat tanggap menanggapi keluhan konsumen (5) dan atribut provider mempunyai jaminan SMS akan cepat sampai (7) adalah atribut yang menurut pengguna sangat penting, namun pada kenyataannya kinerja yang mereka terima masih buruk. 


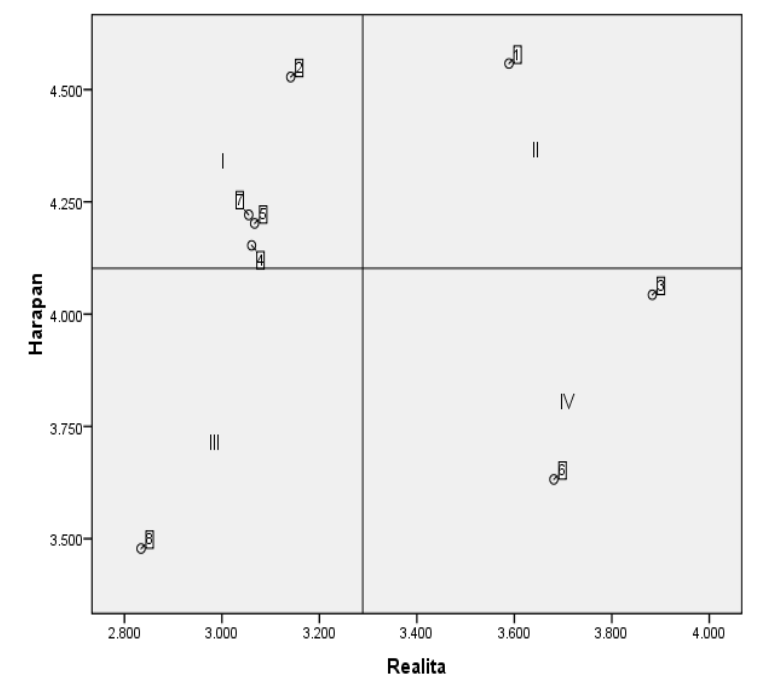

Gambar 2. Diagram Cartesius PerformanceImportance Merek IM3

Atribut yang menurut pengguna sangat penting dan pada kenyataannya kinerja yang mereka dapatkan juga sangat memuaskan adalah atribut kecepatan pengiriman SMS (1). Atribut-atribut yang menurut pengguna tidak penting dan pada kenyataannya kinerja yang diterima juga tidak memuaskan, atribut ini harus ditingkatkan yaitu atribut tersedianya call center 24 jam (8). Dan atribut-atribut yang menurut pengguna tidak penting tapi pada kenyataannya kinerja yang mereka terima sangat memuaskan, item ini dapat terus dipertahankan yaitu atribut keamanan data pelanggan terjaga (3) dan atribut provider mempunyai jaminan pulsa yang hilang akan dikembalikan lagi (6). Gambar 3 adalah paragraf yang menjelaskan pembahasan perceived quality dari merek XL.

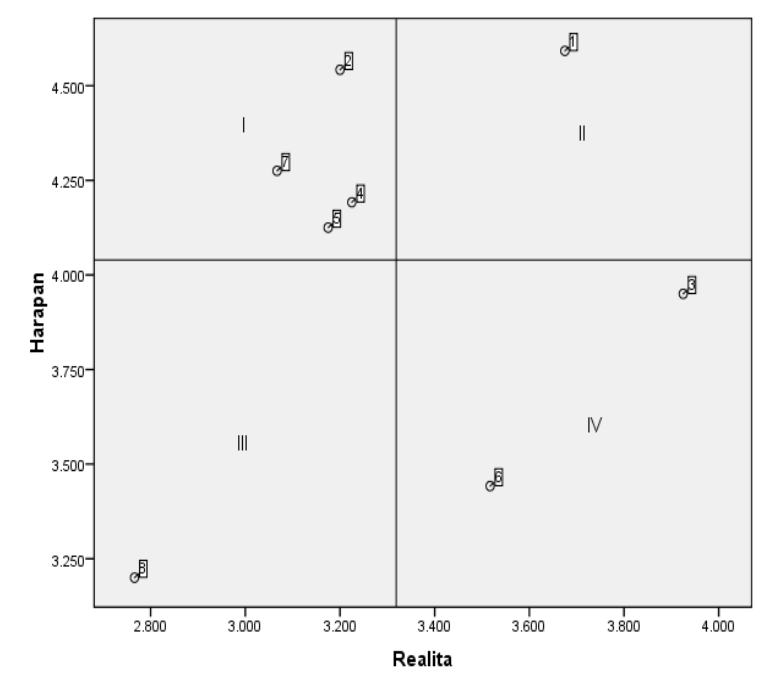

Gambar 3. Diagram Cartesius PerformanceImportance Merek XL

Jurnal Teknik Industri, Vol. X, No. 3, September 2015
Berdasarkan Gambar 3 mengenai diagram performance dan importance dari merek kartu XL terlihat sama dengan diagram performance dan importance dari merek kartu IM3. Dapat kita analisa bahwa atribut jangkauan sinyal luas (2), kecepatan layanan call center (4), atribut cepat tanggap menanggapi keluhan konsumen (5) dan atribut provider mempunyai jaminan SMS akan cepat sampai (7) adalah atribut yang menurut pengguna sangat penting, namun pada kenyataannya kinerja yang mereka terima masih buruk. Atribut yang menurut pengguna sangat penting dan pada kenyataannya kinerja yang mereka dapatkan juga sangat memuaskan adalah atribut kecepatan pengiriman SMS (1). Atribut-atribut yang menurut pengguna tidak penting dan pada kenyataannya kinerja yang diterima juga tidak memuaskan, atribut ini harus ditingkatkan yaitu atribut tersedianya call center 24 jam (8). Dan atribut-atribut yang menurut pengguna tidak penting tapi pada kenyataannya kinerja yang mereka terima sangat memuaskan, item ini dapat terus dipertahankan yaitu atribut keamanan data pelanggan terjaga (3) dan atribut provider mempunyai jaminan pulsa yang hilang akan dikembalikan lagi (6). Paragraf selanjutnya menjelaskan hasil pembahasan brand loyalty dari ketiga merek:

Tabel 3. Rangkuman Hasil Elemen Brand Loyalty

\begin{tabular}{ccccc}
\hline & & \multicolumn{3}{c}{ Merek Kartu Provider } \\
\cline { 3 - 5 } No & Variabel & S & I & X \\
\hline 1 & Switcher & Jelek & Jelek & Jelek \\
2 & Habitual Buyer & Cukup & Baik & Cukup \\
3 & Satisfied Buyer & Baik & Baik & Cukup \\
4 & Liking the Brand & Baik & Baik & Baik \\
5 & Commited Buyer & Baik & Baik & Baik \\
\hline
\end{tabular}

Tabel 3 menjelaskan rangkuman hasil elemen Brand Loyalty.Pada level switcher, bisa kita lihat bahwa semua merek jatuh dalam kategori jelek. Hal ini menggambarkan hasil baik untuk semua merek provider kartu telepon, karena sangat sedikit pelanggan kartu tersebut yang suka berpindah-pindah merek. Pada level habitual buyer semua merek memberikan harapan yang baik, sehingga memberikan gambaran yang cukup menguntungkan buat merek tersebut. Selanjutnya pada level satisfied buyer, bahwa hampir semua merek jatuh dalam kategori baik, kecuali untuk merek kartu XL dimana merek ini masuk kedalam kategori cukup. Sehingga memberikan gambaran yang kurang menguntungkan buat merek tersebut, karena masih sedikit pengguna kartu tersebut yang benar-benar setia dengan merek tersebut.Kemudian untuk liking the brand dan committed buyer, memberikan gambaran yang sama untuk setiap merek provider kartu telepon dimana 
semua merek tersebut jatuh dalam kategori baik. Hal ini berarti pengguna provider kartu telepon tersebut sudah puas dan menyukai produk kartu telepon yang mereka gunakan saat ini. Informasi ini memberikan gambaran yang sangat menggembirakan untuk semua merek kartu tersebut,karena cukup banyak pengguna kartu tersebut yang benar-benar mau untuk menyarankan produknya kepada orang lain.

\section{Kesimpulan}

Beberapa kesimpulan yang dapat diambil dari hasil penelitian ini yaitu dari segi elemen brand awareness merek provider kartu telepon yang berada pada tingkat top of mind adalah Simpati, yang berada pada tingkat brand recall adalah XL, yang berada pada tingkat brandrecognition adalah XL dan yang berada pada tingkat brand unaware adalah XL.

Dari segi elemen brand association, terdapat 7 asosiasi dari 13 asosiasi yang mewakili merek Simpati. Sedangkan untuk merek IM3 dan XL terdapat masing-masing 5 asosiasi yang mewakili merek tersebut.

Atribut asosiasi yang mewakili semua merek providerkartu telepon adalah menyediakan paket internet untuk pengguna smartphone dan kemudahan dalam aplikasi tranfer pulsa, penggunaan nada sambung pribadi (NSP). Sedangkan atribut yang tidak mewakili semua merek adalah tarif paket pengguna smartphone terjangkau dibandingkan tarif kartu pra bayar lain, tarif SMS dan telepon terjangkau dibandingkan tarif kartu pra bayar lain dan produk provider lebih unggul dibandingkan produk sejenis yang diproduksi oleh pesaing.

Dari segi brand perceived quality, semua merek provider kartu telepon yang diuji menunjukkan bahwa terdapat perbedaan kesenjangan antara kinerja persepsi kualitas (performance) dengan harapan persepsi kualitas (importance) dari suatu merek kartu telepon tersebut.

Berdasarkan diagram cartesius performanceimportance, menggambarkan bahwa merek Simpati adalah merek yang memiliki tingkat performance dan importance yang paling baik, hal ini berarti merek
Simpati memiliki brand perceived quality yang kuat. Dan secara berurutan merek provider kartu IM3 dan XL mempunyai tingkat brand perceived quality yang sama.

Bentuk piramida dari elemen-elemen brand loyalty atas merek providerkartu telepon Simpati menggambarkan bentuk piramida yang yang cenderung terlihatideal, yaitu segitiga terbalik. Hal ini menunjukkan bahwa merek providerkartu telepon Simpati tersebut memiliki brand equity yang cukup kuat. Untuk merek provider kartu IM3 dan XL terlihat belum begitu ideal, pada level satisfied buyer dan commited buyer terlihat mengecil. Hal ini menunjukkan bahwa merek provider kartu IM3 dan XL tersebut memiliki brand equity yang tidak terlalu kuat.

\section{Daftar Pustaka}

Aaker, David A. (1991), Managing Brand Equity, San Francisco: Free Press.

Bilson, Simamora.(2001).Memenangkan Pasar dengan Pemasaran Efektif dan Profitabel. Edisi pertama. PT. Gramedia Pustaka Utama, Jakarta.

Durianto, Darmadi dan Sugiarto.(2004).Brand Equity Ten. Gramedia Pustaka Utama, Jakarta.

Durianto, Darmadi, Sugiarto dan Tony.(2001).Strategi Menaklukkan Pasar. Gramedia Pustaka Utama, Jakarta.

Ferrinadewi, Erna.(2008).Merek dan Psikologi Konsumen Implikasi pada Strategi Pemasaran. Graha Ilmu, Yogyakarta.

Goni, Roy.(2007).Playing To Win. Gramedia Pustaka Utama, Jakarta.

Hasan, Ali.(2009).Marketing. Media Presindo, Jakarta.

Kotler, Philip.(2000).Manajemen Pemasaran. Edisi Milenium, Prehallindo, Jakarta.

Rangkuti, Freddy.(2001).Creating Effective Marketing Plan. Gramedia Pustaka Utama, Jakarta.

Tjiptono, Fandy. (2005)Brand Managenent and Strategi. Penerbit: ANDI, Yogyakarta. 